\title{
PENGEMBANGAN BAHAN AJAR IPS BERBENTUK HANDOUT BERMUATAN KEARIFAN LOKAL BALI UNTUK MENINGKATKAN NILAI PEDULI SOSIAL DAN ETIKA LINGKUNGAN
}

\author{
Ni Wayan Ramastuti ${ }^{1}$, Nengah Bawa Atmaja ${ }^{2}$, I Wayan Lasmawan ${ }^{3}$ \\ Program Studi Pendidikan IPS Universitas Pendidikan Ganesha, Singaraja \\ e-mail: niwayanramastuti@gmail.com¹, nengahbawaatmaja@undiksha.ac.id, Iwayanlasmawan@undiksha.ac.id
}

\begin{abstract}
Abstrak
Tujuan penelitian ini untuk mengetahui (1) mengembangkan bahan ajar IPS bermuatan kearifan lokal bali dalam pembelajaran IPS, (2) mengkaji efektivitas penggunaan bahan ajar IPS bermuatan kearifan lokal Bali terhadap nilai peduli sosial dan etika lingkungan siswa SMP Negeri 1 Marga. Penelitian ini menggunakan metode teknik analisis data yang sesuai dengan sifat dan jenis data. Untuk data yang bersifat kualitatif digunakan teknik analisa deskriptif secara logis. Populasi penelitian ini adalah kelas VII G. Pengumpulan data menggunakan observasi. Hasil penelitian menunjukkan bahwa (1) bahan ajar yang berupa handout dengan persetujuan kedua validator sehingga handout tersebut dinyatakan valid atau layak digunakan di lapangan dengan revisi. (2) Efektivitas penggunaan bahan ajar IPS bermuatan kearifan lokal Bali terhadap nilai peduli sosial siswa SMP Negeri 1 Marga sangat efektif setelah diberikan perlakuan (treatment) dengan bukti sikap siswa terkait nilai peduli sosial dan etika lingkungan mengalami peningkatan sebesar $33,49 \%$ dari rata-rata sebelum diberikan perlakuan dengan nilai yaitu 46,28 dan setelah diberikan perlakuan nilai tersebut menjadi naik hingga mencapai angka rata-rata 79,77.
\end{abstract}

Kata Kunci: Handout, Kearifan Lokal, IPS.

\section{Abstrack}

The purpose of this research was to find out (1) developed social studies teaching with Balinese local wisdom in social learning, (2) reviewed the effectivennesof using social studies teaching with Balinese local wisdom towards the social care values and environmental ethichs of Junior high school students at SMP Negeri 1 Marga. This research used data analysis techniques that were in accordance with the nature and type of data. For qualitative data, a logical descriptive analysis technique is used. The population of this research was in the class VII G. The collectionof data used observation. The results showed that (1) teaching in the form of handouts with the approval of the two validators, so that the handouts were declared valid or reasonable to be used in the class with revisions, (2) The effectiveness of using social studies teaching with Balinese local wisdom on the social care values and environmental ethichs of students at SMP Negeri 1 Marga was very effective after being treated evidence of student attitudes related to social care values increased by $33,49 \%$ from the average before being given treatment with a value of 46,28 and after being given treatment the value rose to an average of 79,77.

Keywords: Handout, Local wisdom, Social Sciences.

\section{PENDAHULUAN}

Pendidikan adalah usaha sadar dan terencana untuk mewujudkan suasana belajar dan proses pembelajaran agar peserta didik sacara aktif mengembangkan potensi dirinya untuk memiliki kekuatan spiritual keagamaan, pengendalian diri, kepribadian, kecerdasan, akhlak mulia, serta keterampilan yang diperlukan dirinya, masyarakat, bangsa dan negara (UU Sisdiknas, 2003). Guru merupakan personalia penting dalam pendidikan, selain itu guru merupakan seorang yang hubungannya paling dekat dengan peserta didik. Sebagian besar interaksi yang terjadi di sekolah, adalah interakasi guru dengan peserta didik. Baik melalui proses pembelajaran akademik kulikuler, ekstra kulikuler.

Di sekolah guru merupakan figur yang diharapkan mampu mendidik anak yang berkarakter, berbudaya dan bermoral (Zubaedi, 2013). Guru menjadi fokus utama untuk mewujudkan keberhasilan pendidikan sesuai dengan tujuan pendidikan nasional. Guru juga sebagai panutan siswa dan masyarakat, guru sebagai produser yang membuat dan 
menyusun skenario pembelajaran, karena guru sebagai pemegang estapet terakhir dalam pendidikan untuk menjadikan siswanya menjadi seorang yang berkarakter.

Dalam rangka internalisasi nilai-nilai karakter kepada peserta didik, maka perlu adanya optimalisasi pendidikan. Perlu disadari bahwa fungsi pendidikan nasional adalah mengembangkan kemampuan dan membentuk watak serta peradaban bangsa yang bermartabat dalam rangka mencerdaskan kehidupan bangsa, bertujuan untuk berkembanganya potensi peserta didik agar menjadi manusia yang beriman dan bertaqwa kepada Tuhan Yang Maha Esa, berakhlakul karimah, sehat, berilmu, cakap, kreatif, mandiri dan menjadi warga Negara yang demokratis serta bertanggung jawab (Fatchul, 2011).

Sekolah menengah merupakan salah satu lembaga penyelenggara pendidikan mempunyai tugas menanamkan nilai-nilai karakter kepada peserta didik.Pembelajaran IPS di jenjang SMP bertujuan untuk mengintegrasikan pendidikan lingkungan hidup yang sesuai dengan tujuan pembelajaran IPS. Sehingga siswa mampu berpikir kritis untuk memahami permasalahan sosial dan lingkungan, dan pada akhirnya siswa memiliki kepedulian sosial dan etika lingkungan yang tinggi.

Nilai peduli sosial yang paling ideal dapat dicapai dalam konteks hubungan interpersonal, yakni ketika seseorang dengan yang lainnya saling memahami. Sebaliknya, jika manusia tidak memiliki perasaan kasih sayang dan pemahaman terhadap sesamanya, maka secara mental hidup tidak sehat (Rahmawati, 2017). Nilai peduli sosial banyak dijadikan pegangan hidup bagi orang yang senang bergaul, suka berderma, dan cinta sesama manusia atau yang dikenal sebagai sosok filantropik, yaitu sosok orang yang suka berbuat kebaikan kepada sesamanya. Kebiasaan berderma, menolong orang lain, dan bersikap kasih sayang terhadap sesama merupakan hal yang tidak terpisahkan dari kehidupannya.

Target utama nilai peduli sosial adalah membangun kesadaran-kesadaran interpersonal yang mendalam. Anak dibimbing untuk mampu menjalin hubungan sosial secara harmonis dengan orang lain melalui sikap dan perilaku yang baik. Anak dilatih untuk berprasangka baik kepada orang lain, bekerjasama, suka menolong, menghargai perbedaan pendapat, dan lain sebagainya. Semua perilaku tersebut dapat membantu anak untuk hidup secara sehat dan harmonis dalam lingkungan sosialnya. Muatan nilai peduli sosial dalam pembelajaran IPS sangat dibutuhkan untuk menjadikan siswa berkarakter good citizenship. Kepedulian sosial siswa kelas VII di SMPN 1 Marga secara gradual mengalami penurunan. Hal ini terlihat dari indikator rasa empati siswa terhadap sesama teman dan guru yang semakin memudar. Kenyataan di sekolah menunjukkan adanya berbagai permasalahan yang berakar dari penurunan nilai peduli sosial diantaranya sikap acuh tak acuh dengan teman beda kelas atau kakak kelas, sikap egois yang hanya mementingkan nilai pribadi dibandingkan bekerja dalam kelompok dan sikap arogan yang seringkali berujung pada perkelahian antar-siswa.

Nilai etika lingkungan siswa pun secara perlahan mengalami degradasi. Sejatinya IPS juga merupakan pendidikan lingkungan Hidup yang membangun kesadaran dan kepedulian siswa terhadap lingkungan total (keseluruhan) dan segala masalah yang berkaitan dengannya (Arifin, 2004 dalam Puspitasari, 2016). Sehingga siswa yang memiliki pengetahuan, keterampilan, sikap dan tingkah laku, motivasi serta komitmen untuk bekerja sama, baik secara individu maupun secara kolektif, untuk dapat memecahkan berbagai masalah lingkungan saat ini, dan mencegah timbulnya masalah baru. Degradasi etika lingkungan siswa terlihat dari indikator partisipasi siswa yang rendah dalam menjaga lingkungan secara makro. Siswa yang hanya menjaga kebersihan di lingkungan kelas atau skala mikro tanpa turut serta menjaga kebersihan di lingkungan sekolah, sehingga sampah di lingkugan sekolah di luar kelas dibiarkan berserakan. Salah satu masalah lingkungan yang paling sering terjadi adalah siswa menjadikan kolong meja sebagai tempat penampungan sampah berupa makanan, minuman maupun robekan kertas. Kondisi ini adalah ancaman terhadap etika lingkungan siswa.

Dalam upaya menangani permasalahan tersebut, dan sekaligus membentuk karakter siswa yang peduli sosial dan memiliki etika lingkungan, maka bahan ajar IPS SMP sangat urgen untuk dikembangkan dan diterapkan. Dalam pengembangan bahan ajar IPS ini guru 
dan kekhususan kondisi sosial dan budaya siswa memiliki peranan yang esensial. Peran guru ini dapat dilaksanakan dengan mengembangkan dan menerapkan pembelajaran IPS yang diintegrasikan dengan kearifan lokal Bali. Muatan kearifan lokal Bali dan pembelajaran IPS dipandang tidak hanya akan membentuk nilai peduli sosial dan etika lingkungan siswa, tetapi juga mendekatkan kembali siswa dengan berbagai kearifan lokal Bali. Berdasarkan latar belakang tersebut, maka penelitian ini berfokus pada pengembangan bahan ajar IPS yang diintegrasikan dengan muatan kearifan lokal Bali untuk membentuk karakter peduli sosial dan etika lingkungan pada siswa kelas VII di SMP Negeri 1 Marga.

\section{METODE}

Model pengembangan pembelajaran yang digunakan dalam penelitian ini adalah model desain pembelajaran Dick dan Carey. Sesuai dengan objek dan karakteristik produk yang akan dikembangkan, penggunaan model tersebut diadaptasi sesuai kebutuhan penelitian ini. Prosedur pengembangan yang dilakukan mengikuti sembilan dari sepuluh langkah pengembangan dalam model desain pembelajaran Dick dan Carey. Langkah pengembangannya adalah sebagai berikut: (1) mengidentifikasi tujuan umum pembelajaran, (2) menyusun analisis pembelajaran, (3) mengidentifikasi karakteristik kemampuan awal, (4) merumuskan tujuan khusus pembelajaran, (5) mengembangkan tes acuan kriteria, (6) mengembangkan strategi pembelajaran, (7) mengembangkan dan memilih materi pembelajaran, (8) merancang dan melakukan evaluasi formatif, dan 9) merevisi pembelajaran.

Setelah melakukan semua proses pengembangan, hasil pengembangan selajutnya divalidasi oleh ahli isi/materi, dan ahli desain pembelajaran. Setelah bahan ajar dinyatakan layak oleh kedua ahli tersebut, maka selanjutnya dilakukan proses uji coba. Uji coba dilakukan terhadap empat kategori, yaitu uji coba teman sejawat, uji coba perorangan, uji coba kelompok kecil dan uji coba kelompok besar (uji coba lapangan). Subjek penelitian meliputi kepala sekolah, guru bagian kurikulum, guru kelas, guru mata pelajaran IPS Kelas VII, dan siswa kelas VII di SMP Negeri 1 Marga. Adapun variabel dalam penelitian ini yaitu Variabel pada penelitian ini yaitu:

1. Variabel Independent (Variabel bebas) pada penelitian ini bahan ajar IPS bermuatan kearifan lokal Bali (Tri Hita Karana).

2. Variabel Dependen (Variabel Terikat) pada penelitian ini nilai peduli sosial dan nilai etika lingkungan

Pengumpulan data yang dilakukan yaitu menggunakan teknik wawancara dan teknik dokumentasi. Dalam rangka mencapai penyajian dan pengelompokkan data yang lebih sistematis maka, hasil yang diperoleh dianalisa menggunakan teknik analisa data yang sesuai dengan sifat dan jenis data. Untuk data yang bersifat kualitatif digunakan teknik analisa, deskriptif secara logis.

\section{HASIL DAN PEMBAHASAN}

Dalam prosedur pengembangan rangkaian langkah pelaksanaan pekerjaan yang harus dilaksanakan secara bertahap untuk mencapai tujuan tertentu atau menyelesaikan suatu produk (Dewi, 2007: 87). Tahap pengembangan Dick \& Carey diadaptasi ke dalam penelitian pengembangan ini menjadi 4 tahap. Peneliti berusaha untuk menyesuaikan langkah pengembangan pembelajaran Dick \& Carey dengan langkah pengembangan handout seperti halnya yang telah disampaikan dalam kajian teori. 4 langkah tersebut antara lain:

1) Tahap Analisis Kebutuhan

Tahap ini bertujuan untuk mengkaji tujuan dari produk yang akan dikembangkan. Produk yang akan dikembangkan adalah handout. Peneliti akan melakukan analisis kurikulum untuk menentukan produk yang sesuai dengan tuntutan kurikulum. Analisis kurikulum akan menghasilkan tema yang disesuaikan dengan Kompetensi Isi dan Kompetensi Dasar, serta internalisasi muatan kearifan lokal bali. Selain itu, tahap ini akan menentukan dan menetapkan handout yang akan dikembangkan dalam satu satuan program tertentu. 
2) Tahap Desain Produk

Hasil dari analisis kebutuhan selanjutnya akan menentukan desain produk yang akan dikembangkan. Desain produk harus diwujudkan dalam gambar atau bagan, sehingga dapat digunakan sebagai pegangan untuk menilai dan membuatnya (Sugiyono, 2011: 413). Tahap desain produk kegiatannya meliputi menentukan komponen handout, konsep penyampaian dan pengorganisasian materi, jenis tugas yang diberikan, soal evaluasi, gambar, artikel, contoh-contoh, serta layout handout. Tahap ini akan menghasilkan desain produk awal berupa handout yang sebelumnya telah dilakukan penyusunan instrumen penilaian produk untuk dijadikan pedoman dalam mendesain produk.

3) Tahap Validasi dan Evaluasi

Tahap ini merupakan tahapan inti yang berupa rangkaian penilaian pengembangan produk. Tahapan pra-validasi dilakukan dengan mengkonsultasikan produk awal kepada dosen pembimbing untuk mendapat masukan awal. Tahap pra-validasi berguna untuk menilai kelayakan produk sebelum dinilai oleh validator. Validasi desain merupakan proses kegiatan untuk menilai apakah rancangan produk yang akan dikembangkan secara rasional akan lebih efektif dari yang lama atau tidak.

Validasi terhadap desain awal dilakukan dengan cara meminta ahli/pakar yang sudah berpengalaman untuk menilai produk yang dirancang (Sugiyono, 2011: 302). Ahli/pakar melakukan validasi terhadap produk sehingga akan menghasilkan evaluasi dan saran dalam pengembangan produk. Hasil dari evaluasi dan saran dari ahli/pakar digunakan untuk memperbaiki dan merevisi produk yang sedang dikembangkan.

Rangkaian selanjutnya dari tahap validasi dan evaluasi adalah tahap uji keterbacaan. Produk yang telah dinyatakan layak oleh ahli/ pakar selanjutnya diujikan kepada siswa SMP sebagai calon pengguna. Produk diterapkan ke dalam proses pembelajaran IPS di SMP untuk kemudian siswa menilai dan memberi masukan terhadap modul tersebut. Selain itu, uji keterbacaan juga dilakukan oleh sesama siswa untuk mendapatkan kritik dan saran dalam rangka penyempurnaan produk.

4) Tahap Produk Akhir

Tahap ini akan menghasilkan produk akhir berupa handout yang sudah direvisi berdasarkan kritik dan saran dari tahap validasi dan evaluasi. Produk akhir siap diproduksi secara massal dan disebarkan sebagai handout dalam proses pembelajaran. Dalam penelitian ini pengembangan hanya sampai pada tahap evaluasi formatif. Hasil dari evaluasi formatif dilakukan sebagai masukan atau input untuk memperbaiki produk awal.Pengembangan materi pembelajaran berbasis kearifan lokal (Tri Hita Karana) menghasilkan produk bahan ajar Handout. Pengembangan handout ini merupakan strategi sumber belajar, tambahan yang dilakukan guru untuk meningkatkan efektivitas peserta didik. Langkah-langkah dalam mpengembangan handout adalah melakukan analisis terhadap kurikulum, RPP, dan sumber belajar. Rancangan Draft handout terlebih dahulu dikonsultasikan kepada pembimbing, kemudian di validasi oleh ahli isi. Penilaian terhadap isi pembelajaran dilakukan oleh Dr. Drs. I Putu Sriartha, M.S. dan Dr. Drs. I Wayan Kertih, M.Pd. Hasil penilaian terhadap isi handout adalah sebagai berikut: (1) Total skor maksimal $23 \times 4=92 \ldots$ (a), Jumlah skor total penilaian $=71 \ldots$ (b), Persentase skor total $=\frac{b}{a} \times 100 \%=77,17 \%$ (Baik), (2) Total skor maksimal $10 \times 4=$ $40 \ldots$ (a), Jumlah skor total penilaian $=32 \ldots$ (b), Persentase skor total = $\frac{b}{a} \times 100 \%=80 \%$ (Sangat Baik), (3) Total skor maksimal $9 \times 4=36 \ldots$ (a), Jumlah skor total penilaian $=29 \ldots$ (b), Persentase skor total $=\frac{b}{a} \times 100 \%=80,55 \%$ (Sangat Baik), (4) Total skor maksimal $7 \times 4=28 \ldots$ (a), Jumlah skor total penilaian $=24 \ldots$ (b), Persentase skor total $=\frac{b}{a} \times 100 \%=85,71 \%$ (Sangat Baik).

Jadi dapat disimpulkan hasil validasi ahli isi terkait Handout pembelajaran IPS Bermuatan kearifan lokal Bali (Tri Hita Karana) dikatagorikan baik. Ada beberapa hal yang perlu ditambahkan dan di revisi, sehingga handout pembelajaran IPS Bermuatan kearifan lokal Bali (Tri Hita Karana) layak digunakan di lapangan. 
Pelaksanaan pembelajaran dengan menggunakan handout menunjukkan bahwa siswa tertarik dalam mengikuti pembelajaran, siswa berani menyampaikan contoh - contoh sikap yang mencerminkan peduli sosial dan etika lingkungan, serta guru telah dapat memanfaatkan waktu dengan optimal dalam pengamatan langsung terhadap sikap siswa. Efektivitas penggunaan bahan ajar IPS bermuatan kearifan lokal bali terhadap nilai peduli sosial dan etika lingkungan dilihat dari hasil yang diperoleh siswa pada pretest dan posttest. Berdasarkan hasil pretest dan posttest dari 29 jumlah responden pada umumnya nilai pretest dapat dikatagorikan cukup dengan rata-rata $(46,28)$, sedangkan nilai postest dikatagorikan Sangat baik dengan rata-rata $(79,77)$. Jika dilihat dari hasil pretest terdapat nilai terendah 28,56 berjumlah 5 responden, nilai 42,84 berjumlah 12 responden, nilai 57,12 berjumlah 12 responden. Pada posttest nilai terendah 71,40 berjumlah 16 responden, nilai 85,68 berjumlah 9 responden, nilai 99,96 berjumlah 4 responden. Jika dipersentase kenaikannya terdapat kenaikan 14,28 berjumlah 5 responden, kenaikan 28,56 berjumlah 13 responden, kenaikan 42,84 berjumlah 7 responden, kenaikan 57,12 berjumlah 3 responden. Jadi dapat disimpulkan rata-rata persentase kenaikan 33,49\%. Penggunaan handout sebagai sumber belajar tambahan sudah dapat membantu siswa dalam mempelajari lingkungan sekitar berupa kearifan lokal Tri Hita Karana. Guru perlu mengembangkan materi pembelajaran sehingga wawasan dan cakrawala siswa tidak terbatas pada pemahaman konsep - konsep yang ada pada buku paket semata, tetapi siswa dapat mengkaitkan konsep dengan sikapnya dalam kehidupan sehari - hari. Pengembangan bahan ajar handout bermuatan kearifan lokal bali dapat menambah wawasan siswa terhadap nilai nilai karakter yang dapat digunakan dalam bertahan dan menghadapi persaingan global.

\section{PEMBAHASAN}

Pengembangan sumber belajar sangat diperlukan di SMP N 1 Marga mengingat nilai sikap peduli sosial dan nilai sikap etika lingkungan pada siswa mengalami penurunan (degradasi). Siswa yang seharusnya memiliki sikap respek terhadap teman maupun terhadap lingkungan di sekitarnya. Idealnya tidak terjadi permasalahan sikap acuh tak acuh dengan teman beda kelas ataupun kakak kelas, sikap egois yang hanya mementingkan nilai pribadi di bandingkan bekerja dalam kelompok dan sikap arogan yang sering kali berujung pada perkelahian antar siswa, rasa empati siswa terhadap sesama teman dan guru yang semakin memudar. Begitu juga dengan sikap etika lingkungan siswa pun secara perlahan mengalami degradasi atau penurunan. Seperti contohnya pada kolong meja dijadikan sebagai tempat penampungan sampah berupa makanan, minuman maupun robekan kertas. Rasa respek siswa dari generasi ke generasi mengalami penurunan terhadap lingkungan sekitar. Dari permasalahan tersebut maka dibutuhkan adanya pengembangan bahan ajar IPS bermuatan kearifan lokal Bali dengan tujuan adanya nilai peduli sosial dan etika lingkungan di SMP Negeri 1 Marga.

Pengembangan dan pembentukan karakter diyakini perlu dan penting untuk dilakukan oleh sekolah ataupun masyarakat untuk menjadi pijakan dalam penyelenggaraan pendidikan karakter yang sukses. Kearifan lokal merupakan suatu nilai yang hidup dan dipercayai sebagai sebuah budaya yang dibenarkan dan dihormati masyarakat yang memiliki. Muatan - muatan nilai pada kearifan lokal memiliki kesesuain dengan nilai pendidikan karakter. Peduli sosial dan etika lingkungan merupakan salah satu nilai pada kearifan lokal yang harus diterapkan pada proses pembelajaran. Memahami nilai peduli sosial dan etika lingkungan tidak hanya dapat mengimbangi hak dan kewajiban terhadap sesama manusia maupun terhadap lingkungan, tetapi dapat membatasi tingkah laku dan berupaya mendalikan berbagai kegiatan yang menyakiti sesama maupun merusak lingkungan.

IImu Pengetahuan Sosial (IPS) menjadi suatu mata pelajaran yang dapat mengantarkan siswa untuk dapat menjawab masalah - masalah mendasar tentang individu, masyarakat, pranata sosial, problem sosial, perubahan sosial, dan kehidupan masyarakat berbangsa dari waktu ke waktu. Dalam mencapai tujuan pembelajaran IPS diperlukan suatu landasan yang kuat dan bersentuhan langsung dengan kehidupan dan lingkungan sekitar siswa. Sehingga arah pengembangan bahan ajar IPS berbentuk handout didesain bermuatan kearifan lokal Bali. 
Berdasarkan hasil penelitian menunjukkan bahwa terdapat SKL, KD, dan materi yang sesuai untuk diintegrasikan dengan kearifan lokal bali. Adapun kesesuaian yang didesain antara pembelajaran IPS dengan konsep kearifan lokal Bali adalah sebagai berikut (1) SKL yang paling sesuai adalah SKL yang mengacu pada aktivitas manusia dalam memenuhi kebutuhan, (2) KD yang paling sesuai adalah menganalisis konsep interaksi antara manusia dengan ruang sehingga menghasilkan berbagai kegiatan ekonomi (produksi, distribusi, konsumis, penawaran - permintaan) dan interaksi antar ruang untuk keberlangsungan kehidupan ekonomi, social dan budaya Indonesia, (3) materi yang paling sesuai untuk dikembangkan adalah materi kelangkaan sebagai permasalahan ekonomi manusia, kebutuhan manusia, tindakan, motif dan prinsip ekonomi. Pengembangan materi pembelajaran IPS tersebut diterjemahkan di dalam pengembangan bahan ajar berbentuk handout. Pengembangan handout telah melalui uji validasi oleh validator ahli dari kalangan dosen.

Penilaian pengembangan handout bermuatan kearifan lokal bali dinilai oleh dua validator, validator I memeriksa dan menilai hingga memberikan persetujuan dan memberikan instruksi lanjut ke validator II juga melakukan hal yang sama, yang pertama memeriksa, menilai, hingga memberikan persetujuan untuk lanjut melakukan penelitian di lapangan (SMP Negeri 1 Marga). Adapun aspek yang di validasi, aspek kelayakan isi (kesesuaian materi $\mathrm{KI}$ dan KD, keakuratan materi, pendukung materi pembelajaran, kemutakhiran materi, soal). Aspek kelayakan penyajian (Teknis penyajian, kelengkapan penyajian, tata tulis). Aspek penilaian bahasa (lugas, komunikatif, dialogis dan interaktif, kesesuaian dengan tingkat perkembangan peserta didik). Aspek penilaian sikap peduli sosial dan nilai etika lingkungan. Nilai yang diberikan oleh validator I dan Validator II terdapat 6 nilai yang berada pada katagori sangat relevan dan 1 nilai berada pada katagori relevan, sehingga instrumen ini layak digunakan di lapangan dengan revisi.

Berkaitan dengan penilaian handout terdapat beberapa masukan dari ahli yaitu (1) materi yang dikembangkan pada handout masih perlu diberikan contoh - contoh dengan kehidupan sekitar siswa, (2) kata - kata dalam kalimat lebih disederhanakan agar sesuai dengan kemampuan siswa pada jenjang SMP, (3) gambar - gambar yang disajikan pada handout harus sesuai dengan nilai - nilai peduli sosial dan etika lingkungan. Masukan yang diberikan oleh ahli kemudian dijadikan dasar dalam merevisi handout agar menjadi lebih baik.

Setelah melewati tahap revisi, handout kembali dinilai oleh ahli dan menunjukkan bahwa handout termasuk kategori baik. Pengembangan handout materi IPS yang dilaksanakan oleh Nita (2016) dan Ardana (2018) pada penelitian sebelumnya, juga memperoleh hasil uji dalam kategori baik. Hal ini mengindikasikan bahwa produk yang dikembangkan masih perlu dikembangkan lebih baik lagi, dengan harapan produk yang dibuat dan dikembangkan selanjutnya lebih mampu dan lebih efektif meningkatkan tidak hanya hasil belajar, tetapi pada aspek lain seperti nilai peduli sosial dan etika lingkungan.

Pengembangan bahan ajar IPS merupakan upaya di dalam menjawab permasalahan yang dihadapi oleh guru IPS. Pengembangan bahan ajar ini memberikan pemahaman yang mendalam dan begitu penting kepada peserta didik untuk memahami pentingnya nilai sikap peduli sosial dan nilai sikap etika lingkungan. Berdasarkan kebutuhan tersebut maka dirancang sebuah pengembangan bahan ajar IPS berbentuk handout bermuatan kearifan lokal Bali untuk meningkatkan nilai sikap peduli sosial dan nilai sikap etika lingkungan.

Pengembangan Handout bermuatan kearifan lokal Bali (Tri Hita Karana) yang telah dikembangkan dan telah divalidasi oleh validator I dan validator II menunjukkan bahwa handout pembelajaran IPS yang dikembangkan memiliki katagori layak digunakan di lapangan dengan revisi. Berdasarkan hasil validasi tersebut maka pengembangan bahan ajar IPS berbentuk handout bermuatan kearifan lokal Bali (Tri Hita Karana) yang dikembangkan diterapkan ke dalam proses pembelajaran IPS dengan KI dan KD yang telah dipilih. Penerapan pengembangan bahan ajar IPS bertujuan untuk meningkatkan nilai sikap peduli sosial dan nilai sikap etika lingkungan, sehingga dalam pelaksanaan penerapan bahan ajar berupa handout ini akan dilakukan dalam 1x pertemuan.

Sesuai dengan apa yang diperoleh pada hasil penelitian, penggunaan bahan ajar 
berbentuk handout bermuatan kearifan lokal bali, mampu meningkatkan sikap peduli sosial dan etika lingkungan pada siswa. Presentase yang diperoleh yaitu pada penilaian pretest pada kategori cukup dengan rata - rata 46,28, sedangkan penilaian pada posttest diperoleh persentase kategori sangat baik dengan rata - rata 79,77. Meningkatnya presentase proses belajar tersebut dipengaruhi karena adanya pengintegrasian lingkungan sekitar khususnya lingkungan sekolah dalam penerapan nilai - nilai peduli sosial dan etika lingkungan.

Pada kegiatan pembelajaran sebelum menggunakan handout, siswa masih terlihat biasa - biasa saja dan cenderung kurang aktif, dengan materi yang hanya tersaji pada buku. Hal tersebut terlihat dari raut wajah beberapa siswa. Saat guru menerangkan materi, beberapa siswa masih ada yang kurang memperhatikan penjelasan guru. Begitu juga pada saat proses tanya jawab, tidak semua siswa mencatat hal - hal penting yang diinstruksikan oleh guru. Bahkan kepedulian dari satu siswa dengan siswa lain untuk menegur temennya yang lalai masih dirasa kurang. Selain itu, juga terlihat siswa masih acuh tak acuh dengan teman, guru, cuek terhadap teman disekitarnya dan masih banyak siswa yang membuang sampah tidak pada tempatnya.

Suasana yang berbeda terjadi manakala proses pembelajaran menggunakan handout. Perubahan minat, suasana dan semangat belajar siswa mulai terlihat setelah siswa diberikan bahan ajar berbentuk handout. Saat guru meminta siswa untuk menjawab pertanyaan yang diberikan, siswa terlihat lebih bersemangat. Beberapa siswa lebih senang melihat gambar - gambar yang tersaji pada handout, dimana gambar - gambar tersebut diambil dari keadaan riil dari aktivitas - atkvitas yang pernah dialami siswa.

Beberapa aspek pengamatan proses belajar yang mengalami peningkatan kearah yang lebih baik adalah aspek sikap siswa yang ditunjukkan dari awalnya siswa tidak respek dengan teman menjadi individu yang peduli dengan teman, peduli dengan guru dan peduli dengan lingkungan sekitar. Bahkan jika guru hanya melihatnya secara langsung tanpa disuruh pun siswa sudah mulai sadar mulai dari kebersihan di kelas, kebersihan di luar kelas dan tetap menjaga lingkungan sekitar. Selain itu, aspek aktivitas dan suasana pembelajaran meliputi siswa mencatat hal penting dan terlihat senang mengikuti pembelajaran yang ditunjukkan dari wajah siswa yang berseri- seri.

Pengembangan bahan ajar berbentuk handout bermuatan kearifan lokal bali telah mampu dan efektif meningkatkan nilai peduli sosial dan etika lingkungan. Hal ini terlihat dari adanya perubahan sikap siswa ke arah yang lebih baik saat mengikuti pembelajaran maupun diluar pembelajaran di kelas. Hasil temuan ini sejalan dengan penelitian Noviana, dkk (2014) dengan hasil bahan ajar PIPIS berbasis kearifan lokal membantu guru dalam mengembangkan dan menghubungkan materi pembelajaran dalam mata pelajaran PIPS dengan potensi daerah setempat, yang dibuktikan dengan adanya peningkatan pemahaman siswa dalam mempelajari bahan ajar PIPS berbasis kearifan lokal. Pembelajaran dengan memberikan suplemen materi tambahan yang tersaji pada handout, memberikan inspirasi kepada siswa untuk mencari contoh lain di lingkungan sekitarnya yang mencerminkan adanya peduli sosial dan etika lingkungan.

Penerapan materi pembelajaran IPS telah mampu untuk membantu siswa di dalam menggali dan memahami nilai - nilai kearifan lokal yang dimiliki masyarakat Bali pada umumnya dan lingkungan SMP N 1 Marga pada khususnya. Selain itu, penerapan dan pengembangan bahan ajar IPS bermuatan kearifan lokal Bali dapat membentuk siswa yang mampu bertahan dan beradaptasi dengan arif dan bijaksana di tengah arus globalisasi dengan memegang teguh nilai - nilai peduli sosial dan etika lingkungan. Temuan ini sejalan dengan hasil penelitian Sukadi (2007), yang mengemukakan konteks sosial budaya masyarakat Bali memberikan basis bagi proses reproduksi budaya dalam penyelenggaraan pendidikan IPS yang lebih dimaknai sebagai proses pemerdayaan siswa yang memungkinkan mereka memiliki dan mengembangkan pengetahuan dan wawsan, nilai nilai dan sikap, serta keterampilan sosial secara partisipasif dalam pembelajaran terhadap kehidupan sosial budaya lokal, nasional dan global. 


\section{PENUTUP}

Pengembangan sumber belajar sangat diperlukan di SMP N 1 Marga mengingat nilai sikap peduli sosial dan nilai sikap etika lingkungan pada siswa mengalami penurunan (degradasi). Pengembangan dan pembentukan karakter diyakini perlu dan penting untuk dilakukan oleh sekolah ataupun masyarakat untuk menjadi pijakan dalam penyelenggaraan pendidikan karakter yang sukses. Kearifan lokal merupakan suatu nilai yang hidup dan dipercayai sebagai sebuah budaya yang dibenarkan dan dihormati masyarakat yang memiliki. Muatan - muatan nilai pada kearifan lokal memiliki kesesuain dengan nilai pendidikan karakter. Peduli sosial dan etika lingkungan merupakan salah satu nilai pada kearifan lokal yang harus diterapkan pada proses pembelajaran. IImu Pengetahuan Sosial (IPS) menjadi suatu mata pelajaran yang dapat mengantarkan siswa untuk dapat menjawab masalah - masalah mendasar tentang individu, masyarakat, pranata sosial, problem sosial, perubahan sosial, dan kehidupan masyarakat berbangsa dari waktu ke waktu. Dalam mencapai tujuan pembelajaran IPS diperlukan suatu landasan yang kuat dan bersentuhan langsung dengan kehidupan dan lingkungan sekitar siswa. Sehingga arah pengembangan bahan ajar IPS berbentuk handout didesain bermuatan kearifan lokal Bali. Pengembangan materi pembelajaran IPS tersebut diterjemahkan di dalam pengembangan bahan ajar berbentuk handout. Pengembangan handout telah melalui uji validasi oleh validator ahli dari kalangan dosen. Hasil yang diperoleh dari uji validasi menunjukkan bahwa handout termasuk kategori baik dan dapat digunakan untuk uji coba lapangan. Pada ujicoba lapangan diperoleh hasil penilaian pretest pada kategori cukup dengan rata - rata 46,28, sedangkan penilaian pada posttest diperoleh persentase kategori sangat baik dengan rata rata 79,77 . Hasil tersebut menunjukkan bahwa penggunaan bahan ajar berbentuk handout bermuatan kearifan lokal bali, mampu meningkatkan sikap peduli sosial dan etika lingkungan pada siswa. Hal ini dipengaruhi karena adanya pengintegrasian lingkungan sekitar khususnya lingkungan sekolah dalam penerapan nilai - nilai peduli sosial dan etika lingkungan. Pengembangan bahan ajar berbentuk handout bermuatan kearifan lokal bali diharapkan dapat dijadikan refresnsi sumber belajar tambahan bagi guru - guru IPS dalam upaya pengembangan kompetensi guru dan peningkatan hasil belajar siswa.

\section{DAFTAR RUJUKAN}

Ardana, I Ketut Gede. 2018. "Pengembangan Materi Pembelajaran IPS Berbasis Tri Hita Karana di SMP Negeri 1 Kuta Utara." Tesis (tidak diterbitkan). Universitas Pendidikan Ganesha Singaraja.

Dewi, Salma Prawiradilaga. 2007. Prinsip Disain Pembelajaran. Jakarta : Reneka

Fatchul, Mu'in. 2011. Pendidikan Karakter (Konstruksi Teoretik dan Praktek). Jakarta: Erlangga.

Nita Apsari, Ni Luh Gede. 2016. "Pengembangan Materi Pembelajaran IPS Berbasis Kearifan Lokal Mayarakat Bali (Tri Hita Karana) di SMP Negri 3 Sawan.” Tesis (tidak diterbitkan). Universitas Pendidikan Ganesha Singaraja.

Noviana, Eddy dkk, 2014. Pola Pembelajaran Pendidikan Ilmu Pengetahuan Sosial Berbasis Kearifan Lokal di Kelas IV Sekolah Dasar Negeri 04 Buantan Besar Kecamatan Siak Kabupaten Siak. Jurnal Primary Program Studi Pendidikan Guru Sekolah Dasar Fakultas Keguruan dan IImu Pendidikan Universitas Riau, Volume 3 Nomor 1, april 2014.

Puspitasari, Ratna. 2016. Penanaman Nilai Karakter Peduli Lingkungan Dalam Muatan Environmental Education Pada Pembelajaran IPS Di MI Darul Hikam Kota Cirebon. Al Ibtida, 3(1): 39-56.

Rahmawati, Isna. 2017. Pengintegrasian Nilai-Nilai Dalam Pembelajaran IPS.Magistra, 
100(29): 1-10.

Sugiyono. 2011. Metode Penelitian Kuantitatif, Kualitatif dan R\&D. Bandung: Alfabeta.

Sukadi. 2007. Pendidikan IPS Sebagai Rekonstruksi Pengalaman Budaya Berbasis Ideologi Tri Hita Karana : Studi Etnografi Tentang Pengaruh Mayarakat Terhadap Program Pendidikan IPS Pada SMU Negri 1 Ubud, Bali. Mimbar Pendidikan No. 1/XXVI/2007.

Undang-Undang Nomor 20 tahun 2003 tentang Sistem Pendidikan Nasional

Wibowo, Agus. 2015. Pendidikan Karakter Berbasis Kearifan Lokal di Sekolah. Yogyakarta: Pustaka Pelajar.

Zubaedi. 2013. Desain Pendidikan Karakter: Konsepsi Dan Aplikasinya Dalam Lembaga Pendidikan. Jakarta: Kencana Prenada Media. 